を論じ、且同じ試料から得た試驗值が用ひた試殮片の形によつて如何に影響されるかを述べよ。

\title{
而 地 試 驜
}

1941 年 4 月 30 日（水矅日）

試 﨑 官

J. P. Griffiths, B. Sc., A.I.C., F. I. R. I,

J. G. Mackay, Ph. D., B. Sc., A. I. C.

(解答時間 6 時間)

「抗張力小「破斷時伸長率」及び「モヂュラス」等の言葉の解釋如何。

大きなデーライト (daylight) 型プレス及びショパー機を用ひて、2 種のカーボン黑（夫々 a 及び b)(受驗

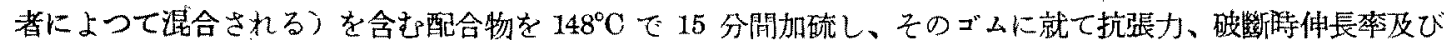
$500 \%$ に於けるモヂュラス等を比較せよ。配合次の如し。

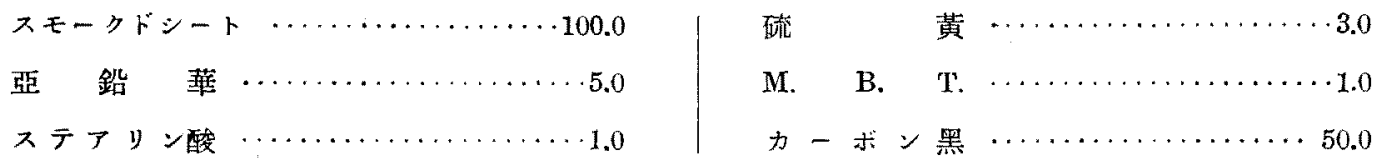

[註〕ショッパー試驗機を用ひる際には助手の嗳助を得ても宜しい。

\section{ヘビア ラテックス固體總含有量と 窒素及灰分との關係}

J. McGavack 及 C. E. Rhines.

$$
\text { I. E. }\ulcorner, 1940,32,: 072
$$

大杉友七譯

本文の目的は一ビア ラテックスの固體總含有量と空素攻灰分との關係を先つ報告寸るにある、次に酸凝縮 に作て製せられたゴム中の窒素はラテ，クスの最初の固體總含有量には無關倸であることを示したい、更に吸 着されたり、溶け込んだり、又はゴム相と直接に艾つた殘留空素は水相に於ける空素の濃度には無關保なる一 定の價を持つと云ふ事を示すのが目的である。斯樣な關倸に對する適切な知識を持つことはより良き生ゴムを 彆する上に助けになると信じられる。

Arisz (1) はラテ,タスの案素含有量を研究した、彼の研究は探收の時間及地方の關係が種々のタ,ビング

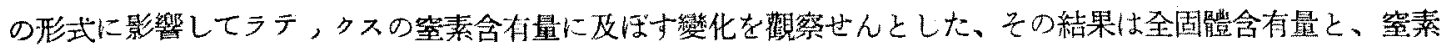
價との間には一つの關保がある事を示してるる。ゴム樹 1 躆に就て取つた彼の数字を使つて、案素をラテッ” スの全固體含有量飞對する百分率で圆取りして見ると（第1期）固體全體の窒素含有量はラデ，クスの固體總 含有量にざつと逆比例する事が判明する。些素含有量が全ラテ，クスの百分䇣になる様にAriszの数值を圖取 る時は $x$ 軸に本行な直線上落付く樣である。Arisz の研究から得た指示に從つて我々は我々の特別區域に於て 
普通のタ，ピング法に依り探取したラテックスの穻素含有量を測定せんとした。我々は亦灰分が固體總含有量 に件つて如何に變るかと云ふことを見るために之等の試料が利用し得る事を斷定した、そして又固體總含有量 の樣々なるラテ，クスを凝固さした場合に窒素がどんな風に配分されるかを決定した。

\section{空素優及灰分に對する手段}

使用したラテ，クス試料は 4 地區から隔月探汁により獲得した。 4 地區に於ける試料探取は各地遌がーーケ月 の正規の休止期間が濟んだ後同時に始められた。研究の月中は各地區から28の試料が探られたか樣にして 112 の試料を集めたがその內 1 だけは取扱中失敗した。この撰ばれたる地區は固體總含有量に於て非常に巽な るラテ，クスを供給して哭れたのである。ラテ，クスを提供する所の樹木の中には老種，子ばえや若い、種子ば え文は多數の若い芽つぎも含まれてるた。

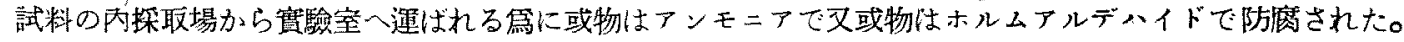

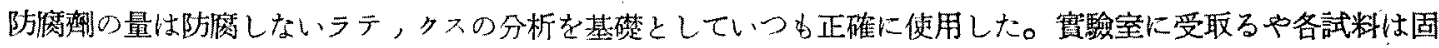
體含有量に對して測定せられ、叉一部は淺いガラス皿に注いで $50^{\circ} \mathrm{C}$ のオーフェンで乾してフィルムにし备

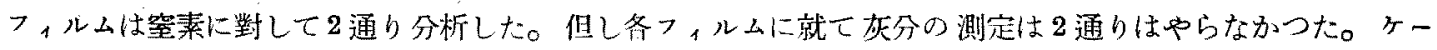
ルダール窒素測定法に依つたのである。

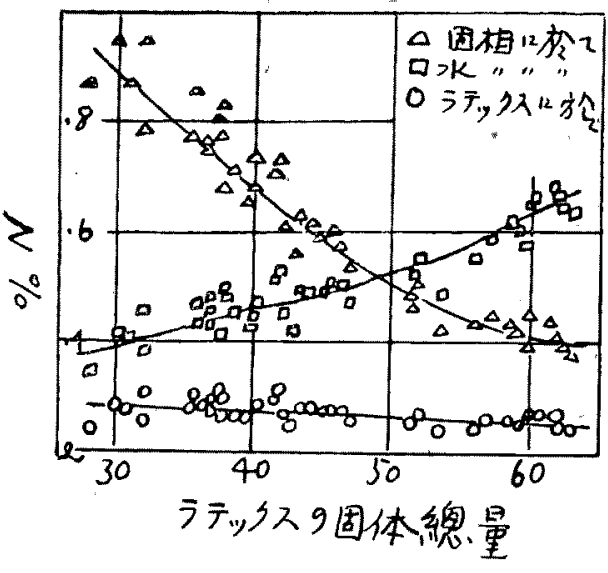

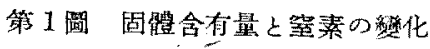
ゴム樹 1 碞によりアリッ ズ氏の數值よ゙り棓算
空素測定に際し揮登性留基の食まれる事を防ぐ用心として 各試料は薄く縮まして分析の直前 $0.33 \% の \mathrm{Na}_{2} \mathrm{HPO}_{4} \cdot 12 \mathrm{H}_{2} \mathrm{O}$

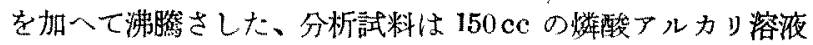
と共にケールダール・フラスコに盛り跷液 25〜50cc となる 迄徐々に沸脚した。 窒素測定はかくしてフラスコ內の残渣に

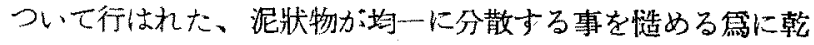
燥组にラテ，タスを注ぐ前にはげしく闃找を實行した之は日 に見える程の量の無機性泥狀物を形成する所のアンモニア性 ラテッタスに對して正確な灰分の数字を得る第めには緊要な 注意耤項なのである。結果か淔接に比較し得る樣に各分析は 全く同一方法で行ふ樣にあらゆる努力が拂はれた。2 の防磨 齌を使用した事は單に試勫の取报上に周知の變化があるだけ で防鹰劑をホルムアルデヒドからアンモニアへ代へた所で灰

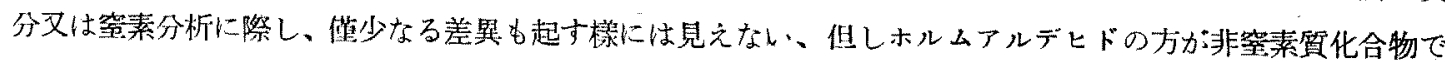
あるから空素含有量を研究するには恐らくより望ましい防修夙である。

總ての分析した試料は国體含有量に從て各組に分類した、各組に對しては 1\% 宛の筑圈でわけた。則ち24

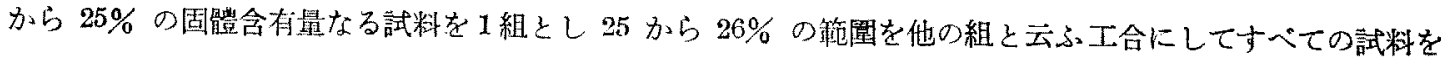

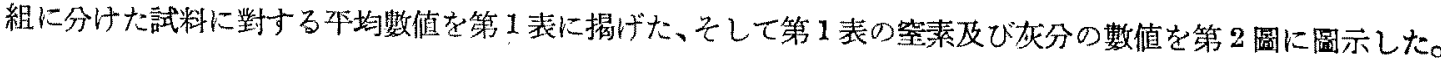
灰分に對しても索素分に對してもカーブが事筫上全く同形なものが得られたのは整くべき事である。この數值

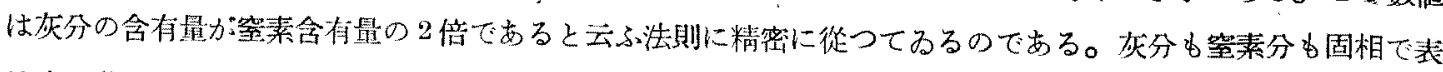

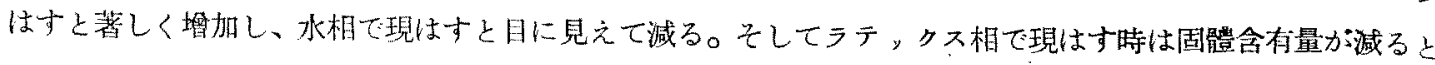

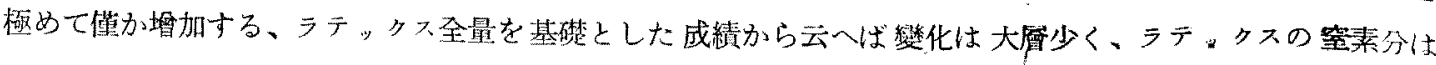




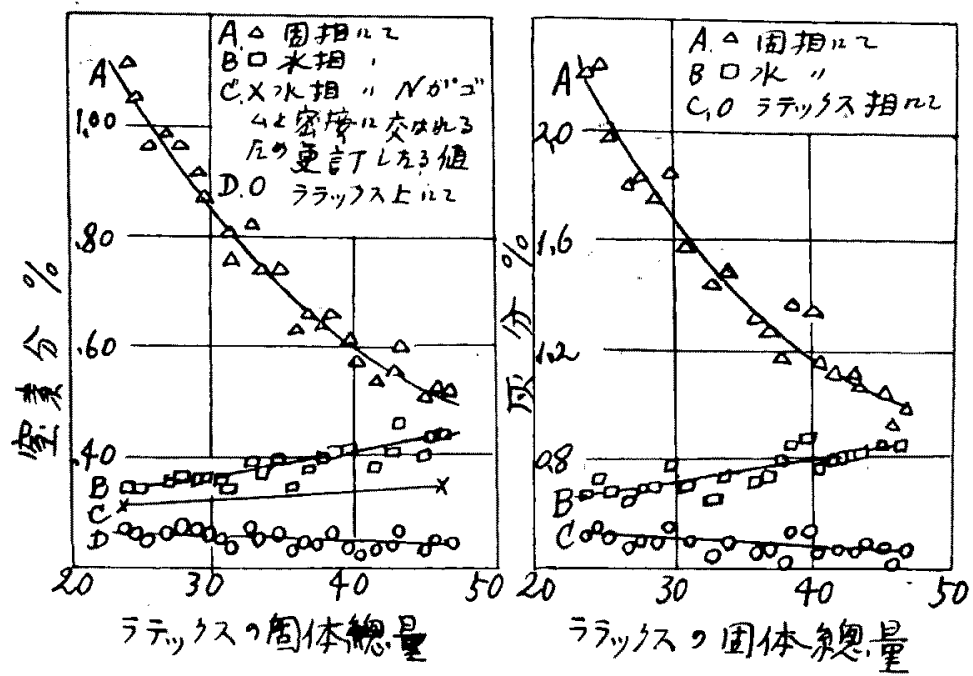

第2 圆

0.25\% で灰分は $0.50 \%$ であると總括的に云つても充分である。灰分と堂素分との間の密接な關係は、ゴム樹

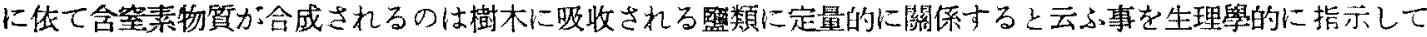
居る。

第】䒾 ラテックス試料に對する本均数值

\begin{tabular}{|c|c|c|c|c|c|c|c|}
\hline 米均 & $\begin{array}{c}\text { ラテックス } \\
\text { の固鲴稳量 } \\
\% \\
\%\end{array}$ & $\begin{array}{c}\text { 固相にて澌 } \\
\text { 定された㯊 } \\
\text { 柔 } \\
\%\end{array}$ & 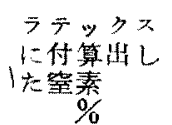 & $\begin{array}{c}\text { 永相にて算 } \\
\text { 出した罢 } \\
\% \\
\%\end{array}$ & $\begin{array}{c}\text { 固相に付专 } \\
\text { 測定した施 } \\
\text { 分 } \\
\%\end{array}$ & $\begin{array}{c}\text { フテッタメ } \\
\text { の灰分計算 } \\
\text { 墨 } \\
\%\end{array}$ & $\begin{array}{c}\text { 水相心 } \\
\text { 算出 } \\
\text { た洃分 } \\
\%\end{array}$ \\
\hline 3 & 46.30 & 0.522 & 0.240 & 0.447 & 1.01 & 0.47 & 0.87 \\
\hline 2 & 45.40 & 0.525 & 0.238 & 0.438 & 0.94 & 0.43 & 0.78 \\
\hline 2 & 44.89 & 0.513 & 0.228 & 0.415 & 1.06 & 0.45 & $0.8 \%$ \\
\hline 2 & 43.12 & 0.613 & 0.265 & 0.465 & 1.09 & 0.48 & 0.83 \\
\hline 8 & 42.68 & 0.561 & 0.239 & 0.417 & 1.12 & 0.48 & 0.83 \\
\hline 3 & 41.24 & 0.545 & 0.227 & 0.383 & 1.13 & 0.47 & 0.80 \\
\hline 2 & 40.16 & 0.578 & 0.233 & 0.385 & 1.15 & 0.46 & 0.77 \\
\hline 3 & 39.59 & 0.625 & 0.236 & 0.410 & 1.35 & 0.53 & 0.88 \\
\hline 10 & 38.42 & 0.663 & 0.255 & 0.414 & 1.37 & 0.53 & 0.86 \\
\hline 7 & 37.55 & 0.646 & 0.241 & 0.403 & 1.18 & 0.44 & 0.71 \\
\hline 4 & 36.61 & 0.663 & 0.241 & 0.380 & 1.28 & 0.48 & 0.74 \\
\hline 1 & 35.62 & 0.635 & 0.225 & 0.350 & 1.30 & 0.46 & 0.72 \\
\hline 1 & 34.63 & 0.740 & 0.255 & 0.395 & 1.35 & 0.47 & 0.71 \\
\hline 5 & 33.48 & 0.745 & 0.250 & 0.375 & 1.47 & 0.49 & 0.74 \\
\hline 2 & 32.58 & 0.825 & 0.268 & 0.395 & 1.37 & 0.45 & 0.66 \\
\hline 5 & 31.28 & 0.765 & 0.238 & 0.344 & 1.44 & 0.45 & 0.66 \\
\hline 4 & 30.75 & 0.814 & 0.251 & 0.358 & 1.58 & 0.49 & 0.70 \\
\hline 9 & 29.52 & 0.875 & 0.257 & 0.364 & 1.84 & 0.54 & 0.77 \\
\hline 8 & 28.48 & 0.921 & 0.263 & 0.367 & 1.76 & 0.50 & 0.70 \\
\hline 9 & 27.56 & 0.967 & 0.268 & 0.367 & 1.83 & 0.50 & 0.69 \\
\hline 6 & 26.71 & 0.990 & 0.265 & 0.360 & 1.81 & 0.48 & 0.66 \\
\hline 4 & 25.42 & 0.966 & 0.246 & 0.329 & 1.99 & 0.51 & 0.68 \\
\hline 5 & 24.56 & 1.053 & 0.257 & 0.343 & 2.23 & 0.55 & 0.73 \\
\hline 6 & 23.58 & 1.113 & 0.263 & 0.341 & 2.21 & $0.5^{2}$ & 0.68 \\
\hline
\end{tabular}




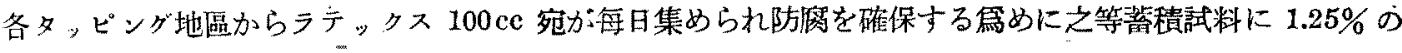
アンモニアを入れた、探收月を便宜上7日づに凅分し得るのであるが、その各7日の採取期間の終りに各地 區に對して集められた $700 \mathrm{cc}$ 部に蒸溜水 $1 l$ で稀釋し、メチルレッドで酸性を呈する迄 $10 \%$ の稘酸委加へ、

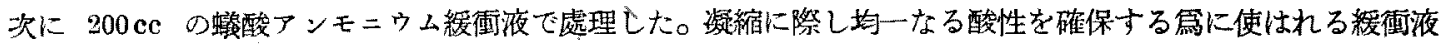
は、10\%の蟶酸を $20 \%$ アンモニアで處理し丁度メチルレッドで酸性を呈する樣にして作製したのである。 緩衝液のスト，クはすべての試料に使用された、この紱㣫液を加へたる後約 1 分にして凝縮した所のラテっク 又試料は一夜放置しタレープ化して乾かす、かくして得た縮んだ試料は、乾燥したラテックス溥膜に就いてや つたと同一の手段に依て 2 可空素に對して分析した(第 2 表)。但し分析に先立ち稀薄なる葫性と共に沸騰して 試料からアンモニア分のなくなる事を確めた。

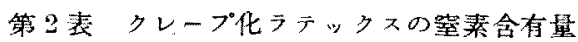

\begin{tabular}{|c|c|}
\hline 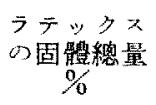 & $\begin{array}{l}\text { クレーブ化 } \\
\text { ゴムが } \\
\%\end{array}$ \\
\hline 44.7 & 0.42 \\
\hline 41.6 & 0.35 \\
\hline 40.6 & 0.37 \\
\hline 38.6 & 0.35 \\
\hline 38.3 & 0.36 \\
\hline 38.2 & 0.40 \\
\hline
\end{tabular}

\begin{tabular}{|c|c|}
\hline 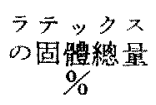 & $\begin{array}{c}タ レ-フ^{\circ} 1 \mathrm{C} \\
\text { ×ム中のN } \\
\%\end{array}$ \\
\hline 37.4 & 0.42 \\
\hline 32.5 & 0.41 \\
\hline 30.9 & 0.47 \\
\hline 29.5 & 0.51 \\
\hline 28.8 & 0.50 \\
\hline 28.5 & 0.52 \\
\hline
\end{tabular}

$\begin{array}{cc}\text { テテックス } & \text { クレープ华 } \\ \text { の固體總量 } & \text { ゴム中心 } \\ \% & \% \\ 27.5 & 0.56 \\ 27.2 & 0.58 \\ 24.7 & 0.55 \\ 24.0 & 0.66\end{array}$

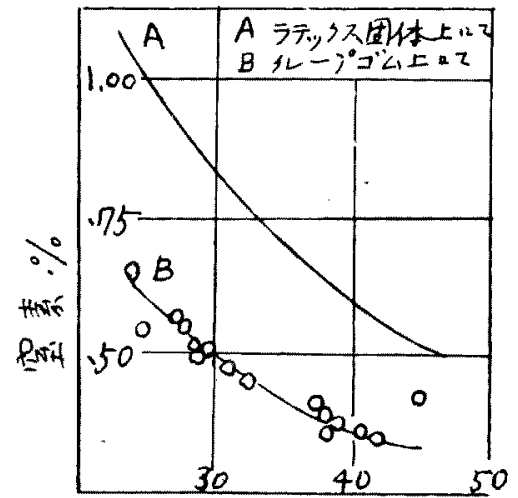

ラテックスク固体總量

第3 㖥 ラテック>0阎體含有 童に伴ふクレープの笡 素含付䁷心磨化
第3圖に於てはタレーブ化試料に對する數值をカーブBにて圖示

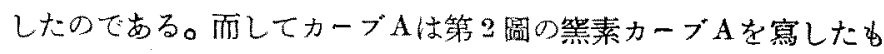
のであるが之は固相で現はされた凝縮前のラテっタス中に存在する 䇺素總量を示寸、ラテ,クス中の空素總量はクレープに現はれる所 では略々 60\%でる事が第3圆から明かである。一般に酸凝樎ば ラテ，クス獎液中にあたりまへに分散してるる含空素物䓄の $57 \%$ 以上ゴムの部分と密接に交つてクレープ中の含有物肉に全堂素が含 まれると云ふ結果になる。

\section{ラテックス中に於て等素はゴムと密接に交はる}

前章に於て等素がラテッタスのゴム部分と親しく交はつてるる事 を照會した、之は空素が゙ム粒子の上にしつかりと結着して從てク リーミンダを繰かへしても烧ひ去り得ないのである。タッーミング 操作は一般にゴム炭化水素を溶解性の䈨液成分乙遊離するのであ

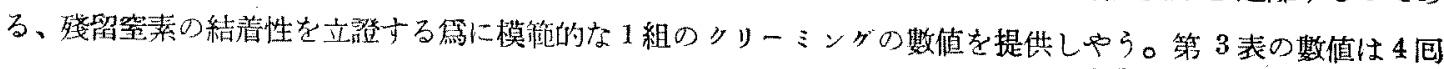

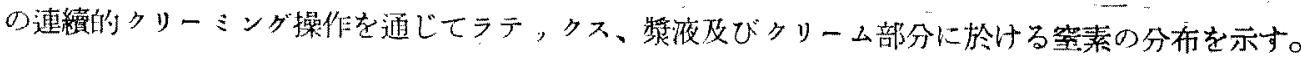


第3表 ラテックメ中の塋素分布

試料

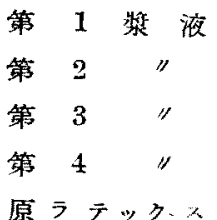

第 $13 y-\infty$

第 2 "

第 3 "

第 4 "
試料の數.

\section{$\mathrm{g}$}

1287

859

625

549

2524

1243

1046

923

726

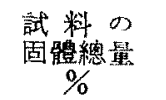

6.53

2.70

0.763

0.798

32.7 a

60.15

58.8

55.1

57.7
試料のN䑁
$\%$
(濕法)

0.228

0.078

0.029

0.012

0.197

0.158

0.092

0.072

0.067
$\mathrm{N}_{\mathrm{g}}$

2.930

0.670

0.181

0.066

4.970

1.968

0.960

0.667

0.486
$100 \mathrm{~g}$ \%

ゴムと交

は3 $\mathrm{N}$

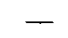

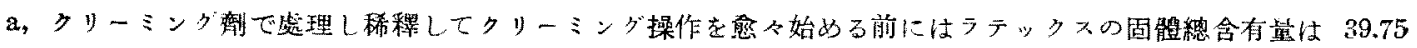

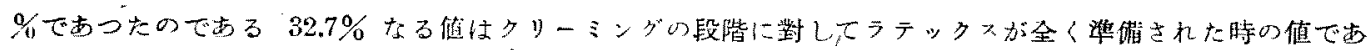
उ。

\section{コムと交はれる空零の計草}

かメるクリーミング操作とは不慣れな計算方法を明かにする第めに 1 例を示さう、100 g の第 1 クリーム中 の殘留窒素は次の如くして計算する。100 $\mathrm{g}$ の第 1 クリームは $60.15 \mathrm{~g}$ の固體と $39.85 \mathrm{~g}$ の水を含む、クリ一ム

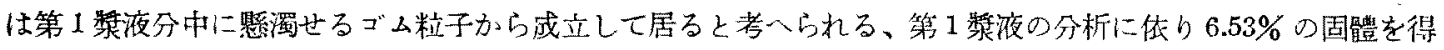

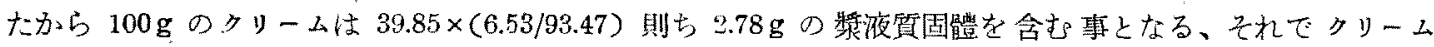

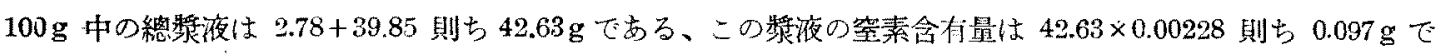
ある、揫夜窒素 $0.097 \mathrm{~g}$ をクリーム中の全空素量 $0.158 \mathrm{~g}$ から減ずるとクリームのゴム分と直接に交つてるる 窒素 $0.061 \mathrm{~g}$ 残生、このゴム分は $60.15-2.78=57.37 \mathrm{~g}$ の量となる、 $(0.061 / 57.37) \times 100$ 則ち $0.106 \mathrm{~g}$ の空菜 がクリーム中のゴム各 $100 \mathrm{~g}$ と交つてるる事々なる、粎 $0.1 \%$ なる空素の此の值は多少翼なつた方法て測定し た McGavack（2）の數值とよく一致するのである、4间目の嶈液分之最後のクリーム分中とに見出された窒 素老合計すると $4.333 \mathrm{~g}$ となつた、試料の記錄に低れば更に分析の䉆めに分け移した試料中に等素か～ $0.577 \mathrm{~g}$

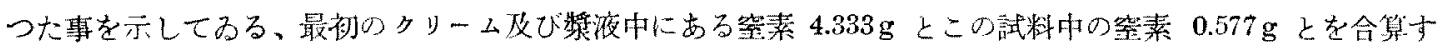
ると $4.910 \mathrm{~g}$ に上るが、ラテ,クス原液中の空素分 $4.970 \mathrm{~g}$ を旨く㜔明して居るのてある。酸に低て㠜縮した

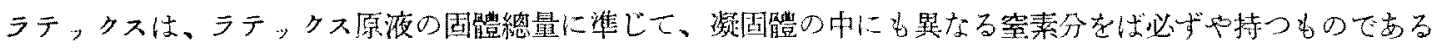
と云ふ事を上記の數傎が示して居る、且亦此の数值は、製品を均一ならしもる第めにはこの㠜国作業は同一條 件一固體總含有量を同一にする條件の下に行ふのが大切である事を示して居る。

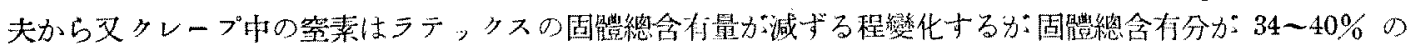

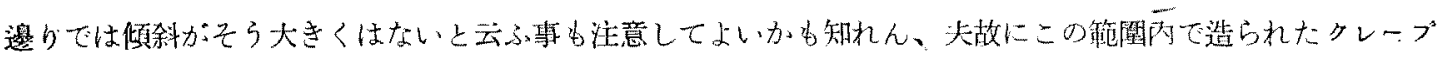
・は34\% 以下の固體分をもつラテ，クスから慗造されたタレープよりも變化が少くなるであらら、このカーブ

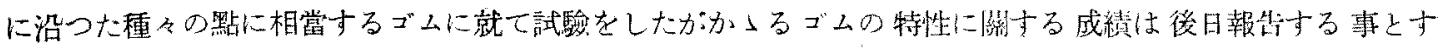
る。

交衕

1. Arisz, Arch, Rubbercultnur, 1920, 4, 30; 1924, 8, 425

2 McGavack, I.E.C., 1939, 31, 1509 